\author{
Özkan Ulutaş, \\ Hülya Taşkapan, \\ Funda Sarı, \\ Mustafa Şenol
}

\section{An Epidermolysis Bullosa Patient Complicated with Chronic Renal Failure}

\author{
Epidermolizis Bülloza Tanısıyla İzlenen Olguda \\ Kronik Böbrek Yetmezliği
}

\section{Abstract}

A 32-yr-old man with epidermolysis bullosa presented with clinical and laboratory findings of chronic renal failure. The patient was supposed to be suffering from mesangial IgA glomerulonephritis in view of the repeated persistent macroscopic episodes of hematuria and raised serum IgA levels, especially polimeric IgA. Because continuous vascular access could not be established, the patient died due to uremia and sepsis. Renal complications are associated with life-threatening problems in this inherited mechanobullous disease because it is impossible to obtain a continuous vascular access or a continuous peritoneal access. The possibility of IgA nephropathy should be considered in patients with epidermolysis bullosa. They should be periodically set up screened for IgA levels and hematuria.

Key words: Epidermolysis bullosa, kidney failure, chronic

\title{
Őzeł
}

Epidermolizis bülloza (EB) tanısıyla takip edilen 32 yaşında erkek hasta, kronik böbrek yetmezliğinin klinik ve laboratuvar bulgularıyla başvurdu. Tekrarlayan persistan hematürisi olan ve özellikle polimerik IgA olmak üzere serum IgA düzeyleri yüksek olarak saptanan hastada mezengial IgA glomerulonefriti düşünüldü. Sürekli vasküler yol sağlanamayan hasta sepsis ve üremi nedeniyle kaybedildi. Bu ailesel mekano-büllöz hastalıkta kronik vasküler ya da kronik periton yolu sağlanamadığı için renal komplikasyonlar hayatı tehdit eden problemlere neden olabilir. Epidermolizis bülloza hastalarında IgA nefropatisi intimali göz önünde bulundurulmalıdır. Hastalarda hematüri ve serum IgA düzeyleri periyodik olarak takip edilmelidir.

Anahtar kelimeler: Epidermolizis bülloza, böbrek yetmezliği, kronik

\section{Introduction}

Epidermolysis bullosa (EB) is a rare genetic disease characterized by the presence of extremely fragile skin and recurrent blister formation, resulting from minor mechanical friction or trauma. The most obvious signs are vesicles and bullae within the skin and mucous membranes. Inside the body, such as the linings of the mouth, esophagus, stomach, intestines, lungs, bladder, and genitals may also be involved and clinical heterogenity is a manifestation of a variety of heritable molecular defects. There are three main forms of inherited EB: EB simplex, junctional EB and dystrophic EB (DEB). These different subtypes are defined according to the depth of blister location within the skin layers. In EB, secondary renal amyloidosis, urological complications such as genitourinary tract stricture and post-infectious glomerulonephritis have all been reported (1-5). Although it is known that $\lg \mathrm{A}$ nephropathy may complicate several dermatosis such as dermatitis herpetiformis, psoriasis, EB complicated by IgA nephropathy has been thought to be rare $(1$, t6-8). We described a patient with junctional or dystrophic EB associated with possible lgA nephropathy.

\section{Case}

A 34-yr-old man who have been followed for EB in the Dermatology Department of our center for 6 years presented with the 
symptoms of dyspnea, nause, and vomiting. He had a history of skin fragility in response to mechanical trauma beginning from birth. The patient's sister died of the same disease in her 29. He was diagnosed as EB when he was seven years old. The skin biopsy taken 3 years ago from the perilesional skin adjacent to a fresh blister, hematoxylin-eosin and periodic acid-schiff (PAS) stainings showed subepidermal blister formation. PAS-positive basement membrane was found on the floor of blisters. It was reported that he had not come routine visits in Dermatology Department for two years. Renal function and blood biochemistry values were normal two years ago. The patient reported no other medications except some topical steroids and topical antibiotics. Physical examination on admission revealed cachexia. Multiple fragile blisters were observed all over his body. He had nail loss and dystrophy and dental enamel hypoplasia. The patient was afebrile, had a blood pressure of $90 / 60 \mathrm{mmHg}$, and a rate of 108 beats/min. On laboratory examination, hematocrite was $21 \%$, WBC count was $10,100 / \mathrm{mm}^{3}$, platelet count was 273,000 / $\mathrm{mm} 3$, and erythrocyte sedimentation rate was $50 \mathrm{~mm} /$ hour. Blood urea nitrogene (BUN) was $162 \mathrm{mg} / \mathrm{dl}$, creatinine of 10.6 $\mathrm{mg} / \mathrm{dl}$, total protein of $6.7 \mathrm{~g} / \mathrm{dl}$, albumin of $1.7 \mathrm{~g} / \mathrm{dl}$, alkaline phosphatase (ALP) of $115 \mathrm{IU} / \mathrm{l}$, uric acide of $7.8 \mathrm{mg} / \mathrm{dl}$, Na of $132 \mathrm{mEq} / \mathrm{l}, \mathrm{K}$ of $5.3 \mathrm{mEq} / \mathrm{l}, \mathrm{Ca}$ of $8.7 \mathrm{mg} / \mathrm{dl}, \mathrm{P}$ of $7.7 \mathrm{mg} / \mathrm{dl}$, and parathyroid hormone level (intact PTH) was $170 \mathrm{pg} / \mathrm{ml}$. Proteinuria was not detected. Urine examinations revealed dysmorphic hematuria. Other laboratory results included negative tests for hepatitis $B, C$, antinuclear antibody and cryoglobulins. Complement levels were within normal limits. IgA levels were $720 \mathrm{mg} / \mathrm{dl}$ (normal 45-380 mg/dl). Serum immunofixation electrophoresis revealed high polymeric $\lg A$. On renal ultrasound, the kidneys measured 8.7 and $9.2 \mathrm{~cm}$ on the right and left, respectively, with increased echogenicity consistent with chronic kidney disease. No evidences of obstruction, mass or renal stones were observed. Significant increases in serum $\lg \mathrm{A}$ (polymeric $\lg \mathrm{A}$ ) and hematuria episodes were detected in the hospital records of the patient during the follow-up of Dermatology Department. The patient was started intermittent hemodialysis treatment through jugular vein catheterization. After ten days catheter was removed by the reason of extensive bullous lesions and infection findings on the insertion site. Because of the same

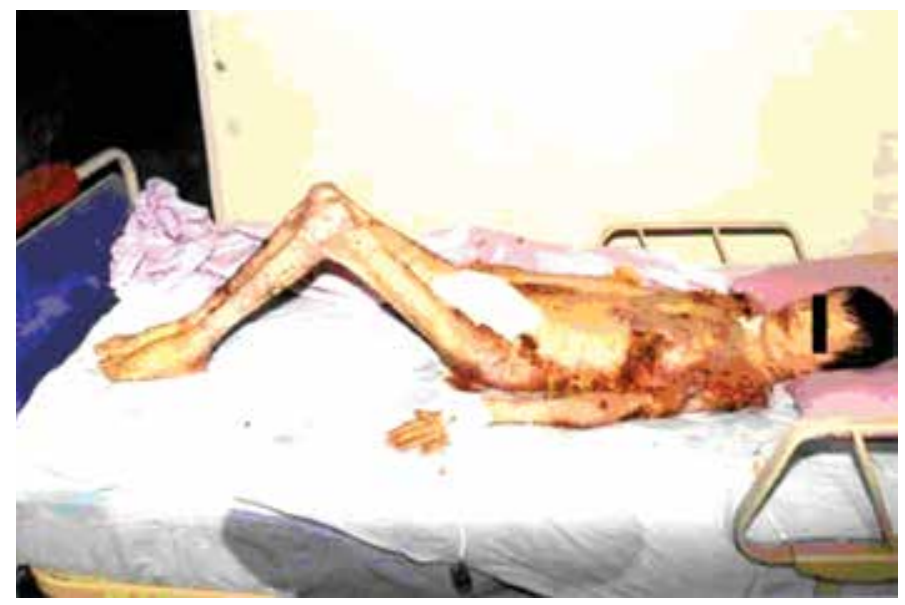

Figure 1. Multiple fragile blisters on all over the body problems catherizations were repeated 6 times. The patient died of uremia and sepsis because continuous vascular access could not be established. Unfortunately, in this case postmortem kidney biopsy could not be performed because of the patient's parent refusal.

\section{Discussion}

IgAnephropathyis a mesangial proliferativeglomerulonephritis characterized by diffuse mesangial deposition of IgA. IgA is the most abundant immunoglobulin in the body and primarily concerned with mucosal defence. Mucosal antigen challenge provokes polymeric $\lg \mathrm{A}(\mathrm{plg} \mathrm{A})$ production by plasma cells of the mucosa-associated lymphoid tissue, the plgA is transported across epithelium into mucosal fluids. Circulating IgA is bone marrow-derived and mostly in monomeric $\lg A(\mathrm{mlg} A)$ form. The mesangial $\lg A$ in $\lg A$ nephropathy is plgA. The clinical association with mucosal infection originally suggested that the mesangial plgA comes from the mucosal immune system, as most plgA is mucosally derived. In our patient prominent IgA was polymeric $\lg A$. Genitourinary tract stricture does not seem to be a likely cause of the chronic renal failure (CRF) in this case. Likewise post infectious glomerulonephritis is unlikely, as complement levels were normal (6-10).

IgA mesangial deposits have been reported to be associated with some diseases involving mucosa such as ulcerative colitis and celiac disease. Common denominator that could explain the development of IgA mesangial deposits in these diseases is unknown. It is known that the onset or exacerbation of $\lg A$ nephropathy is often preceded by a respiratory tract infection or infections at other locations a few days earlier. Level of serum IgA is elevated in about half of the patients with IgA nephropathy. In $40-50 \%$ of cases, the clinical presentation is episodic hematuria (6-9). EB is also one of the cause of AA type renal amyloidosis. In amyloidosis, proteinuria, mainly albuminuria, occurs in the absence of hematuria (5). In our patient proteinuria was not detected. Renal biopsy is the gold standart for diagnosis of IgA nephropathy. However, we could not performed because of the patient's parent refusal. The patient might be suffering from mesangial IgA glomerulonephritis in the view of the repeated persistent macroscopic episodes of hematuria and raised serum $\lg \mathrm{A}$ levels, especially plgA.

Renal complications are associated with life-threatening problems in this inherited mechanobullous disease, because it may be impossible to obtain a vascular access. In English literature, a patient with recessive dystrophic EB who performed succesful peritoneal dialysis for 14 months was reported (11). Peritoneal dialysis catheter needs an approximately $10 \mathrm{~cm}$ tunnel under skin before entering the abdomen. Our patient had bullae, chronic ulcers, granulation tissue, and infection around the exit site of the hemodialysis catheter. We didn't insert peritoneal dialysis catheter because we thought that the patient could have similar skin reactions like hemodialysis catheter. The possibility of IgA nephropathy should be considered in patients with EB and patients should be periodically screened for $\lg A$ levels and hematuria. 


\section{References}

1. Cuesta-Estellés G, Escobedo-Rumoroso JM, Garcés-López L, et al. Epidermolysis bullosa and chronic renal failure. Nephrol Dial Transplant 1998;13:2133-4.

2. Mann JF, Zeier M, Zilow $E$, et al. The spectrum of renal involvement in epidermolysis bullosa dystrophica hereditaria: report of two cases. Am J Kidney Dis 1988;11:437-41.

3. Reitelman C, Burbige KA, Mitchell ME, et al. The urological manifestations of epidermolysis bullosa. J Urol 1986;136:1320-2.

4. Yamada Y, Dekio S, Jidoi J, et al. Epidermolysis bullosa atrophicans generalisata mitis--report of a case with renal dysfunction. J Dermatol 1990;17:690-5.

5. Clarkson AR, Woodroffe AJ, Bannister KM, et al. The syndrome of IgA nephropathy. Clin Nephrol 1984;21:7-14.
6. Feehally J. Immune mechanisms in glomerular IgA deposition. Nephrol Dial Transplant 1988;3:361-78.

7. Van Es LA. Pathogenesis of IgA nephropathy. Kidney Int 1992;41:1720-9.

8. Gündüz K, Vatansever $S$, Türel $A$, et al. Recessive dystrophic epidermolysis bullosa complicated with nephrotic syndrome due to secondary amyloidosis. Int J Dermatol 2000;39:151-3.

9. Donadio JV Jr, Grande JP. Immunoglobulin A nephropathy: a clinical perspective. J Am Soc Nephrol 1997;8:1324-32.

10. Farhi $D$, Ingen-Housz-Oro $S$, Ducret $F$, et al. [Recessive dystrophic epidermolysis bullosa (Hallopeau-Siemens) with IgA nephropathy: 4 cases]. Ann Dermatol Venereol 2004;131:963-7.

11. Ahmadi J, Antaya R. Successful peritoneal dialysis in a patient with recessive dystrophic epidermolysis bullosa. Pediatr Dermatol 2007;24:589-90. 